Tomasz Albiński* (iD http://orcid.org/0000-0003-0316-1734

Gnieźnieńska Szkoła Wyższa Milenium w Gnieźnie

Katarzyna Miłek ${ }^{* *}$ (iD http://orcid.org/0000-0003-4603-4604

Gnieźnieńska Szkoła Wyższa Milenium w Gnieźnie

https://doi.org/10.25312/2083-2923.18/2020_10takm

\title{
Recenzja książki Dziecko i dzieciństwo w badaniach pedagogicznych, red. nauk. Marzenna Magda-Adamowicz, Ewa Kowalska, Wydawnictwo Adam Marszałek, Toruń 2020, ss. 364
}

Dziecko i dzieciństwo to dla pedagoga zagadnienia niezmiernie istotne. Ważne na tyle, by ciągle pogłębiać i uaktualniać wiedzę. Publikacja zatytułowana Dziecko i dzieciństwo w badaniach pedagogicznych pod redakcją M. Magdy-Adamowicz i E. Kowalskiej rzuca nowe światło na problematykę pojmowania dzieciństwa i badań tegoż tematu. Czytelnik czerpie wiedzę o tym, jak zmieniło się zgłębianie istoty dzieciństwa na przestrzeni lat. W obecnym ujęciu dziecko to istota „unikalna”, ,inna”, która nie jest skażona „dorosłą perspektywą," która posługuje się odmiennym kodem kulturowym. Dziecko jest osadzone przede wszystkim w świecie faktów i emocji. W tej rzeczywistości żyje, przyjmując ją za coś oczywistego i stałego. Jest to jednak strefa niewystarczająca dla niego, dlatego bardzo często stanowi punkt wyjścia do skonstruowania świata

" Tomasz Albiński - doktor nauk humanistycznych w zakresie filozofii. Dziekan Wydziału Nauk Społecznych Gnieźnieńskiej Szkoły Wyższej Milenium. Dziedziny badawcze: logika, metodologia, etyka. Autor monografii Spór o realizm modalny oraz artykułów z zakresu filozofii analitycznej.

Katarzyna Miłek - doktor nauk społecznych w zakresie pedagogiki. Adiunkt na Wydziale Nauk Społecznych w Gnieźnieńskiej Szkole Wyższej Milenium. Dziedziny badawcze: twórczość, pedagogika przedszkolna, arteterapia. Autorka wielu artykułów w czasopismach naukowych, jak również w monografiach. 
własnego. Tym samym rzeczywistość dziecka ma charakter wyjątkowo dynamiczny, gdyż jest determinowana swoistą korelacją dwóch odmiennych światów: dziecka i dorosłych. Fenomen ten w dużym stopniu odpowiada za swoistość pedagogiki dziecka jako takiej. Biorąc pod uwagę fakt występowania różnych, często spornych ujęć metodologicznych tematu pedagogiki dziecka, autorzy recenzowanej pracy prezentują liczne kontrowersje, jak również zbieżne i rozbieżne refleksje wielu autorów. Książka wnosi nowe spojrzenie na zjawiska już rozpoznane i opisane, jak również przyczynia się do odkrycia innowacyjnych znaczeń. Bez wątpienia może stać się źródłem inspiracji dla badacza zgłębiającego temat pedagogiki dziecka.

Publikacja zawiera dwadzieścia zwięzłych tekstów, w których autorzy analizują poszczególne wątki wspomnianej tematyki. Ciekawe i inspirujące wywody poszerzają horyzonty spojrzenia na podany temat.

W celu lepszego uporządkowania dyskutowanej problematyki książkę podzielono na cztery części. Pierwsza z nich jest najogólniejsza i nosi tytuł Metodologiczna tożsamość pedagogiki dziecka. Autorzy tej części pracy zasadniczo starają się wskazać i scharakteryzować specyfikę szczególnego rodzaju badań w naukach społecznych, jakimi są badania rzeczywistości najmłodszych podmiotów życia społecznego - dzieci. Druga część pracy, zatytułowana Konwencjonalne badania sytuacji dziecka, poświęcona jest wybranym, popularnym metodom i technikom badań w pedagogice, $\mathrm{w}$ których przedmiotem badania są partykularne sytuacje, $\mathrm{z}$ jakimi mierzy się dziecko. Część trzecia (Jakościowe badania dzieciństwa - wybrane obszary) traktuje o zagadnieniu badań jakościowych, przy czym proponowane przez autorów analizy mają charakter bardziej abstrakcyjny i spekulatywny - dotyczą one bowiem badania fenomenu dzieciństwa jako takiego (przedmiotem badania jest już zjawisko, nie osoba). Ostatnia część pracy (Istota badań $w$ działaniu) może być potraktowana jako swoista klamra spinająca dotychczasowe dywagacje, a także jako ich podsumowanie - wzbogacone jednak o silnie podkreślany przez autorów tej części recenzowanej pracy wymiar praktyczny. Atutem pracy jest odwoływanie się jej autorów do szerokiego grona specjalistów, będących reprezentantami różnych opcji metodologicznych zarówno z zakresu nauk społecznych, jak i humanistycznych. Dzięki temu udało się stworzyć pluralistyczny obraz dyskutowanych zagadnień, pozwalający czytelnikowi zapoznać się z ich złożonością i nieoczywistością; daje on również okazję do ukazania aktualności problemu i dynamiki jego badań.

W pierwszym rozdziale zatytułowanym Znaczenie teorii $w$ badaniach społecznych - konstruowanie rzeczywistości i jej interpretacji Piotr Mikiewicz pisze w duchu Popperowskim o roli teorii w badaniach empirycznych, w szczególności o konstruowaniu szeroko rozumianego przedmiotu badania, które dokonuje się w trakcie badania samego, oraz o determinantach jego interpretacji. Autor zastanawia się, jak opisywać świat, w jaki sposób objaśniać „działanie” rzeczywistości. Podaje różne modele myślenia, definiuje teorię naukową, podkreślając, że nie każdy zbiór pojęć nią jest, co ma niebagatelne znaczenie przy konstruowaniu procesu badawczego i interpre- 
tacji danych. Dla Piotra Mikiewicza uprawianie nauki to specyficzna forma opowiadania o świecie; ta optyka metodologiczna jest istotna dla problematyki poruszanej w recenzowanej pracy, gdyż rzeczywistość dziecka, dzieciństwo, już samo w sobie jest konstruktem kulturowym, pewną formą „opowieści” o świecie.

$\mathrm{Na}$ uwagę zasługuje również artykuł autorstwa Magdaleny Cuprjak pt. Miejsce podmiotu w przestrzeni paradygmatów nauk pedagogicznych. Rozważania autorki dążą do zogniskowania poszczególnych założeń dających się wskazać we współczesnej myśli pedagogicznej wokół kilku osi, które składają się na paradygmaty. Punktem wyjścia podejmowanych analiz jest omówienie wpływu założeń (ontologicznych, epistemologicznych i metodologicznych) na przedmiot badań (s. 32-35). Jest to podejście umożliwiające autorce $\mathrm{z}$ jednej strony uchwycić wielowymiarowość samego problemu paradygmatu, z drugiej zaś - wskazać na często nieuświadamiane przez badaczy źródła pojawiających się problemów czy przyjmowanych przez nich rozwiązań. Wątpliwości jednak budzą stwierdzenia autorki dotyczące właśnie wspomnianej świadomości badaczy - nie jest bowiem tak, że badacz najpierw określa założenia ontologiczne (s. 32), następnie w oparciu o nie dokonuje wyboru założeń epistemologicznych (s. 34), by na koniec dobrać odpowiednie założenia metodologiczne (s. 34). Tak zarysowana „procedura” jest pewnym idealizacyjnym modelem postawy badacza, który w praktyce badawczej raczej nie występuje - zazwyczaj jego uwaga skupiona jest na doborze odpowiednich narzędzi; nierzadko implikowane przez ten wybór ontologie potrafią badacza zaskoczyć, gdyż nie współgrają z przyjmowaną intuicyjnie przez niego wizją świata (zagadnienia te są szeroko dyskutowane na gruncie filozofii nauki). Przy okazji: epistemologia nie jest dziedziną filozofii nauki (s. 33) - to filozofia nauki została w pewnej mierze wyodrębniona z nurtu badań epistemologicznych. Zaś empiryzm i racjonalizm to nie są główne twierdzenia epistemologiczne - to stanowiska bądź kierunki (na przykład na gruncie epistemologii). W miarę zwięźle i czytelnie Magdalena Cuprjak podaje podstawowe założenia paradygmatów badawczych. Jest to niełatwe zadanie, gdyż kluczowe pojęcie paradygmatu w ujęciu samego T. Kuhna (głównego twórcy idei paradygmatu w nauce) pozostaje niedoprecyzowane (warto przywołać wynik M. Masterman, która wskazuje na dwadzieścia jeden różnych znaczeń wyrażenia paradygmat w samej tylko Strukturze rewolucji naukowych Kuhna). Owa pierwotna niejasność pojęcia paradygmatu może być przyczyną występowania w tekście pewnych niefrasobliwości; przykładowo autorka definiuje paradygmat jako „wewnętrznie spójny system zbudowany na podstawie odmiennych i niemożliwych do połączenia założeń" (s. 35). Jest oczywiste, że z niemożliwych do połączenia założeń nie zbuduje się systemu. Zwraca uwagę czytelnika próba podkreślenia przez autorkę nierzadko pomijanego wymiaru badań - mianowicie płaszczyzny aksjologicznej, wyraźnie zarysowującej się w dyskutowanym obszarze badań pedagogicznych.

Nie bez powodu w tejże części publikacji znalazło się miejsce dla inspirującego wywodu Stanisława Palki, który pisze o wiązaniu podejścia ilościowego z podejściem jakościowym w badaniach empirycznych w pedagogice. Autor wyjaśnia, co wcale nie 
jest oczywiste, czym jest pedagogika, edukacja, a czym kształcenie i wychowywanie. Wymienia, w czym odzwierciedla się wielowymiarowość człowieka. Podane w przystępny sposób informacje te dla zgłębiającego temat badacza z pewnością okażą się cenną wskazówką w dalszych rozważaniach. Dowie się on, na czym powinny opierać się badania ilościowe w badaniach pedagogicznych, a także jaka jest podstawa podejścia jakościowego tejże dziedziny. Sednem opracowania jest jednak łączenie tych dwóch ujęć. Czytelnik dowie się, że wiązanie podejścia jakościowego i ilościowego przynosi badaczowi korzyści, prowadzi do szerszego poznawania procesów wychowania, samokształcenia i kształcenia człowieka.

Temat wspomnianych podejść w ujęciu do pedagogiki kontynuują Mirosława Nyczaj-Drąg i Klaudia Żernik w artykule pt. Projektowanie badań ilościowych i jakościowych w pedagogice dziecka. Autorki odpowiadają na niektóre z pytań dotyczących problematyki projektowania badań naukowych z uwzględnieniem codzienności dziecka. Dokonują przeglądu studiów literatury skupiającej się nad przebiegiem procesu badawczego w badaniach dzieciństwa o charakterze ilościowym. Zaznaczają, że badania wykorzystujące metody ilościowe pozwalają na generalizowanie wyników. Badaczki pochylają się nad projektowaniem badań jakościowych, podkreślają ich zróżnicowanie, by wreszcie przejść do analizy porównawczej wspomnianych ujęć metodologicznych. Autorki otwarcie przyznają, że nie wyczerpały tematu. Przyczyną takiego stanu rzeczy nie jest jednak brak wiedzy w tym zakresie, ale wielowątkowość i rozległość tematyki.

Sporo cennych informacji na temat współczesnych ujęć problematyki dzieciństwa wnosi Małgorzata Kowalik-Olubińska w artykule pt. Słuchanie dziecięcych głosów w procesie badawczym - perspektywa etyczna. Akcentuje ona zmianę, jaka dokonała się w zakresie postrzegania dzieci i ich roli w przestrzeni społecznej, wspominając o „nowej socjologii dzieciństwa”. W paradygmacie tym wychodzi się z założenia, że dzieci (podobnie jak dorośli) mają wpływ na swoje życie, ale i na życie i postępowanie innych osób. Stąd dążenie do słuchania dziecięcych głosów, do zrozumienia świata dziecięcego i założenie, że najważniejszym źródłem wiedzy o dzieciach są one same. Autorka porusza zasadnicze kwestie etyczne dotyczące badań z udziałem dzieci, podkreślając problem uzyskania zgody na udział w badaniach nie tylko od rodzica, ale i od dziecka. Niezwykle istotne są również kwestie związane z psychiką dziecka oraz poufnością informacji ujawnionych badaczowi, o czym autorka nie omieszkała przypomnieć.

O roli metodologii językoznawstwa kognitywnego w procesie identyfikacji potencjału dziecka pisze Wiga Bednarkowa. To także ważny głos w dyskusji dotyczącej pedagogiki dziecka, zaznaczający podstawy interdyscyplinarnej metodologii kognitywizmu. Przytaczając opinie najważniejszych i najbardziej cenionych badaczy kognitywizmu, dotyka tematyki gestaltu, prototypu, znaczenia symbolu. Tekst przydatny będzie głównie badaczom zgłębiającym zawiłe, acz ciekawe teorie kognitywizmu.

Rozdział drugi (Konwencjonalne badania sytuacji dziecka) przynosi kilka ciekawych ujęć tegoż tematu. Z artykułu zatytułowanego Rozpoznawanie sytuacji dziecka, 
czyli o sondażu diagnostycznym Marzenny Magdy-Adamowicz czytelnik dowie się, w jakim celu stosuje się metodę sondażu diagnostycznego. Wyniesie informacje dotyczące diagnozy i poszczególnych etapów sondażu diagnostycznego. Autorka opisuje ponadto jego role i najważniejsze funkcje, jak również najważniejsze i najczęściej zadawane pytania. Podane zostały także trudności, jakie można napotkać przy realizacji sondażu. Te informacje przydatne będą badaczowi, który takowy sondaż planuje bądź przeprowadza.

W innym artykule ta sama autorka pochyla się nad problemem gromadzenia informacji o sytuacji dziecka i jego dzieciństwie, pisząc o ankiecie, obserwacji i wywiadzie. Wspomniane elementy są niezwykle istotne i pomocne przy odkrywaniu przyczyn powstawania problemów rozwojowych u najmłodszych. Marzenna Magda-Adamowicz opisuje badanie ankietowe jako niezastąpione w badaniach pedagogicznych narzędzie poznania cech zbiorowości, faktów i opinii oraz „wiedzy wyjściowej” o dziecku. Wylicza sposoby prowadzenia badań ankietowych, jednocześnie podpowiadając, w jaki sposób można je przeprowadzać. Opisywana następnie obserwacja polega na gromadzeniu danych metodą spostrzeżeń i dostarczaniu najwięcej naturalnych, obiektywnych i prawdziwych informacji o osobie/osobach obserwowanych. Autorka wymienia rodzaje obserwacji dzieci i jej etapy. Jako uzupełnienie powyższych narzędzi czytelnik dowie się więcej na temat wywiadu. Autorka wyjaśnia, czym jest wywiad i jakie są jego rodzaje. Podkreśla komplementarność wspomnianych narzędzi.

Swoją cegiełkę dotyczącą diagnozy dziecka dokłada Krystyna Żuchelkowska, pisząca o eksperymencie jako metodzie badawczej w pedagogice dziecka. Podkreśla, że eksperyment pedagogiczny ma na celu podnoszenie skuteczności kształcenia, korekcji zachowań, wzbogacania wartości w modelowaniu osobowości ucznia. Podaje, kiedy ów eksperyment można wykorzystać, czym w ogóle jest eksperyment pedagogiczny i jakie warunki są potrzebne do jego przeprowadzenia. Opisuje wady i zalety eksperymentu, podkreślając, że jest on ważną metodą badawczą w pedagogice empirycznej. Tekst nie jest wolny od pewnych „potknięć”. Warto by chociaż w przypisie wytłumaczyć stosowane skróty - domysłowi czytelnika pozostawia autorka znaczenie wykorzystywanych zmiennych, takich jak „grupa E” czy „grupa K” (s. 165). Zapewne chodzi o grupę eksperymentalną i grupę kontrolną - jednak autorka winna założyć, że nie każdy czytelnik jest obeznany z owym standardowym oznaczeniem. Jest też poważniejszy błąd: na stronie 167 charakterystyce poddany jest jeden z planów eksperymentalnych, tzw. plan trzygrupowy, z podwojonym pomiarem początkowym i jednym pomiarem końcowym zmiennej zależnej. Podana przez autorkę charakterystyka jest niepoprawna. Przywołany schemat zawiera błąd - z oznaczeń wynika, iż na grupie kontrolnej K2 nie jest dokonywane żadne działanie badawcze. W takim razie czemu w ogóle ma służyć wyróżnienie tej grupy? Jaka jest jej rola w badaniu? Skoro nie są na niej dokonywane żadne działania, jest ona po prostu zbędna. Tak oczywiście nie jest - po prostu zabrakło na schemacie oznaczenia dokonania w grupie K2 pomiaru początkowego (które błędnie pojawia się w przypadku grupy eksperymentalnej E - 
w tym planie eksperymentalnym bowiem nie dokonuje się pomiarów początkowych na grupie E). Autorka nie wspomina też o najważniejszym elemencie tego planu czasie pomiędzy kolejnymi pomiarami. To właśnie wykorzystanie równego odstępu czasu w planie ma wykluczyć, iż obserwowana zmiana została wywołana przez czynnik dojrzewania. Byłoby też wartością dodaną, by w tekście poświęconym eksperymentom w pedagogice dziecka więcej uwagi poświęcić aspektom etycznym.

Urszula Szuścik natomiast pochyla się nad ciekawym, choć niejednokrotnie bagatelizowanym przez pedagogów, tematem rysunku dziecka. Artykuł pt. Rysunek dziecka źródłem wiedzy o nim zwraca uwagę na interdyscyplinarność badań nad twórczością rysunkową dziecka i złożoność problematyki tejże twórczości. Autorka zaznacza, że praca plastyczna jest niczym innym jak wyrazem uczuć dziecka, jego zdolności intelektualnych, poziomu rozwoju fizycznego, poziomu rozwoju społecznego czy świadomości percepcyjnej. Podaje aspekty, które są istotne przy analizie rysunku dziecka. Podkreśla czynniki wpływające na twórczość dziecka, zaznaczając, jak ważny jest stosunek rodzica/rodziców do pierwszych form twórczości dziecka. I wreszcie opisuje dziecięcy rysunek jako narzędzie diagnozy rozwoju dziecka. Zauważa, że poznanie dziecka przez jego twórczość jest dla nauczyciela szansą nie tylko na poznanie wychowanka, ale i wychwycenie jego obaw czy problemów.

Marzenna Magda-Adamowicz raz jeszcze zabiera głos. Tym razem analizuje relacje społeczne w grupie dzieci. Pisze o istocie i procesie badań socjometrycznych. To zwięzłe opracowanie zainteresuje badaczy skupiających swą uwagę na badaniu relacji dziecka w grupie rówieśniczej. Autorka podaje techniki socjometryczne oraz etapy ich realizacji. Podpowiada, jak analizować i interpretować wyniki technik socjometrycznych.

Stanisław Palka koncentruje się w rozdziale drugim na temacie dziecka będącego obiektem i partnerem w badaniach pedagogicznych.

Badając pedagogikę dzieciństwa i chcąc poszerzyć wiedzę na ten temat, warto sięgnąć po rozdział trzeci pt. Jakościowe badania dzieciństwa - wybrane obszary. Znaleźć w nim można bowiem artykuł Agnieszki Nowak-Łojewskiej zatytułowany Fenomenografia jako strategia jakościowa $w$ badaniach pedagogicznych nad edukacja dzieci. Autorka przybliża w nim pojęcie fenomenografii, prezentuje genezę badań fenomenograficznych oraz podstawy i tło teoretyczne tychże badań. W bardzo jasny i przejrzysty sposób ukazuje także różnice między fenomenologią i fenomenografią. Prezentuje najważniejsze cele, przebieg i organizację badań fenomenograficznych oraz możliwości ich zastosowania. Dziedzina ta, choć nieczęsto wykorzystywana w badaniach pedagogicznych, może być przydatna w poszukiwaniu nowych możliwości i perspektyw dla badań pedagogicznych.

Iwona Kopaczyńska w tekście Pomaganie uczniom w dążeniu do rozumienia siebie. Badanie dokumentów $w$ ujęciu jakościowym $z$ wykorzystaniem perspektywy fenomenograficznej poszerza temat wspomnianej dziedziny. Podkreśla, że badane dokumenty to „pisemne wypowiedzi nauczycieli dotyczące znaczenia, jakie nadają pojęciom: 
rozumienia siebie oraz nauczycielskiemu pomaganiu uczniom w dążeniu do rozumienia siebie". Owe dokumenty pomagają ujawnić nauczycielskie perspektywy myślenia. Badanie dokumentów w ujęciu jakościowym w perspektywie fenomenografii jest pomocne w ujawnieniu tego, czego nie widać na pierwszy rzut oka, ujawnieniu niewidocznej od razu głębi.

Aspekt podejścia biograficznego w badaniach z dziećmi porusza Ewa Kowalska. Przytacza biografizację dzieciństwa jako uzasadnienie dla wykorzystania podejścia biograficznego w badaniach z dziećmi. Z kolei Mirosława Nyczaj-Drąg pochyla się nad wywiadem narracyjnym w badaniach jakości wczesnej edukacji dziecka. Pokazuje jedną z możliwości metodologicznych poznania jakości wczesnej edukacji dziecka w rodzinach z klasy średniej. Przypomina, że potencjalnymi źródłami materiału empirycznego dokumentującego doświadczenie życiowe ludzi są biografie, autobiografie czy historie życia osobistego. Cenne okazują się także wspomniane wywiady narracyjne.

Jeszcze inną koncepcję prezentuje Ewa Kowalska, pisząc o studium przypad$\mathrm{ku}$ jako strategii badawczej $\mathrm{w}$ badaniach $\mathrm{z}$ dziećmi. Autorka podaje różne tradycje w metodologii badań pedagogicznych w Polsce. Mówi o różnych sposobach uprawiania i definiowania case study. Podaje odpowiedź na pytanie, jakie cechy powinien posiadać przypadek, który mógłby stać się przedmiotem badań case study. Badacze zainteresowani tematem konceptualizacji przypadku po lekturze artykułu poszerzą z pewnością swoją wiedzę.

Ostatni rozdział książki zatytułowano Istota badań $w$ działaniu. Charakterystykę badań w działaniu ze szczególnym uwzględnieniem problemu integracji społecznej prezentuje Krystyna Chałas w tekście pt. Integracyjne wymiary badań w działaniu. Szanse i bariery kreowania procesu badawczego. Autorka dzieli się własnym doświadczeniem w prowadzeniu badań w działaniu oraz prezentuje perspektywę dalszych badań nad optymalizacją warunków integralnego rozwoju i wychowania ucznia. Za znaczącymi badaczami wylicza cechy badań w działaniu. Podkreśla trudność w prowadzeniu tychże badań w edukacji ze względu na wiele uwarunkowań, takich jak czynniki osobowościowe inspiratora badań.

Temat badań w działaniu wedukacji kontynuuje Iwona Paszenda w artykule Szkolna codzienność twórcza dziecka inspiracja badania $w$ działaniu $w$ edukacji studentów pedagogiki. Podejmuje dyskusyjny temat reform szkolnych. Podkreśla, że model szkoły oparty na kierowniczej roli nauczyciela wyręczającego uczniów w formułowaniu problemów nie sprzyja kształtowaniu i rozwijaniu twórczości. Pisze o wciąż niezadowalającym postępie jakościowym w uczelniach pedagogicznych.

Badaniom interwencyjnym w edukacji dziecka przyglądają się Bogusława Dorota Gołębniak i Beata Zamorska. Podają współczesne warianty badań w działaniu. Opisują społeczną sytuację rozwoju jako przedmiot badań, podkreślają ich ciągły rozwój. Podają przykład badań interwencyjnych, zaznaczając, że obiektywna analiza środowiska przedszkola wykazuje duże bogactwo i zróżnicowanie społecznych interakcji. 
Na zakończenie podano szeroką, wyczerpującą bibliografię dotyczącą opisywanych tematów. Może ona okazać się cenną wskazówką do jeszcze dokładniejszego zgłębienia interesujących badacza tematów.

Książka bez wątpienia skłania do głębszej refleksji na temat badania dziecka i jego dzieciństwa. To przestrzeń bardziej stwarzająca możliwość dialogu niż podania gotowego przepisu na badanie w pedagogice dziecka. Praca jest adresowana przede wszystkim do studentów pedagogiki i pracowników naukowo-dydaktycznych zainteresowanych tematem pedagogiki dziecka. Wyjaśnia, jak diagnozować i jakich narzędzi używać. Inspiruje, wspierając jednocześnie osobistą refleksję metodologiczną badaczy. Zawarte w pracy informacje przyczyniają się do pogłębiania wiedzy o dziecku i jego dzieciństwie w różnych aspektach, dlatego warto po nie sięgnąć, zajmując się wspomnianymi zagadnieniami. 